\title{
DRY GRASSLAND TYPES IN THE PRESPA NATIONAL PARK (NW GREECE), INCLUDING THE SOUTHERN- MOST OCCURRENCE OF THE PRIORITY HABITAT TYPE "PANNONIC SAND STEPPES" (CODE 6260)
}

\author{
Georgios FOTIADIS ${ }^{1, *}$, Michael VRAHNAKIS ${ }^{2}$, Yannis KAZOGLOU $^{3} \&$ \\ Ioannis TSIRIPIDIS ${ }^{4}$
}

\begin{abstract}
A recently completed project on the Natura 2000 sites of Prespa National Park revealed that the area hosts 49 habitat types according to the EU classification, of which eight have a narrowly restricted distribution in Greece. The priority habitat type "* 6260 Pannonic sand steppes" is reported here for the first time for Greece. The new locality represents its southernmost occurrence on the Balkan Peninsula. The aim of this paper therefore is to describe the Greek stands of this habitat type, investigate the factors affecting its occurrence and discuss the associated conservation issues. This is based on a total of 87 relevés sampled for this study and 8 additional relevés from the literature. The relevés were classified by applying TWINSPAN and ordinated using Detrended Correspondence Analysis (DCA). Six vegetation units could be distinguished. One of these corresponds to the habitat type *6260 and was found exclusively on inland sand dunes. Syntaxonomically, we assigned this unit to the alliance Sileno conicae-Cerastion semidecandri s.l. of the class Koelerio-Corynephoretea. Its occurrence in the study area seems to be determined by climatic factors, as well as by the sandy substrate, while anthropogenic disturbances such as grazing also appear to be beneficial to some degree. Apart from the Koelerio-Corynephoretea, another five grassland classes were distinguished in the national park, namely the Thero-Brachypodietea, Stellarietea mediae, Festuco-Brometea, Daphno-Festucetea and funcetea trifidi.
\end{abstract}

Key words: Habitats Directive, Koelerio-Corynephoretea, phytosociology, Sileno conicae-Cerastion semidecandri, syntaxonomy.

\section{Izvleček}

Nedavno končani projekt o območjih Natura 2000 v Narodnem parku Prespa je pokazal, da je na območju po EU klasifikaciji 49 habitatnih tipov, od katerih jih je osem z ozko razširjenostjo v Grčiji. Pojavljanje prednostnega habitata “*6260 Panonske stepe na peščenih tleh" v Grčiji objavljamo prvič. Nova lokacija predstavlja najjužnejše pojavljanje na Balkanskem polotoku. Namen članka je opisati sestoje tega habitatnega tipa v Grčiji, preučiti dejavnike, ki vplivajo na njegovo pojavljanje in razpravljati o vprašanjih, povezanih z njegovim ohranjanjem. Raziskava temelji na 87 vegetacijskih popisih in 8 dodatnih popisih iz literature. Popise smo numerično obdelali s pomočjo TWINSPAN klasifikacije in $\mathrm{z}$ uporabo korespondenčne analize $\mathrm{z}$ odstranjenim trendom (DCA). Ločili smo šest vegetacijskih enot. Ena ustreza habitatnemu tipu in smo jo našli le na celinskih peščenih sipinah. Sintaksonomsko smo jo uvrstili v zvezo Sileno conicae-Cerastion semidecandri s.l. in razred Koelerio-Corynephoretea. Njeno pojavljanje v preučevanem območju je pogojeno s klimatskimi dejavniki in peščeno podlago, antropogene motnje, kot na primer paša, pa do neke mere nanjo vplivajo pozitivno. Poleg travišč razreda Koelerio-Corynephoretea smo v parku našli še pet travišč iz razredov Thero-Brachypodietea, Stellarietea mediae, Festuco-Brometea, Daphno-Festucetea in Funcetea trifidi.

Ključne besede: Habitatna direktiva, Koelerio-Corynephoretea, fitosociologija, Sileno conicae-Cerastion semidecandri, sintaksonomija.

\footnotetext{
${ }^{1}$ Department of Forestry and M. N. E., TEI of Sterea Ellada, Mpakogianni str., Karpenissi, 36100, Greece, gfotiad95@ gmail.com

${ }^{2}$ Department of Forestry and M. N. E., TEI of Thessaly, Terma Mavromihali str., Karditsa, 43100, Greece, mvrahnak@ teilar.gr

${ }^{3}$ Society for the Protection of Prespa (current address: Municipality of Prespa), 53077, Greece, ykazoglou@gmail.com,

${ }^{4}$ School of Biology, Aristotle University of Thessaloniki, P. O. Box 104, 54124, Greece, tsiripid@bio.auth.gr
} 


\section{INTRODUCTION}

The recently accomplished project to record, assess and map the rangeland and forest habitat types of the Natura 2000 sites of the National Park of Prespa ("Ethnikos Drymos PresponGR1340001" and "Ori Varnounta-GR1340003") revealed an exceptional diversity of plant species and habitats. The national park hosts 49 habitat types (19 more than those recorded in 2000), 70 vegetation types and more than 2,100 vascular plant species (almost 30\% of the Greek flora) with 194 considered as important according to Annex II of the Habitats Directive (Vrahnakis et al. 2011). Seven habitat types are of conservation priority according to Annex I of the Directive 92/43/EEC (Habitats Directive); they occupy $26 \%(11,000 \mathrm{ha})$ of the total area of the national park. Eight of the recorded habitat types have quite restricted distribution in Greece. In the previous report on habitat types of the national park in 2000 (Dafis et al. 2001), three grassland priority habitat types (indicated with "**) from a total of 31 types had been documented. The new mapping in 2011 revealed four dry grassland priority habitat types $\left({ }^{*} 6210,{ }^{*} 6220,{ }^{*} 6230\right.$ and $\left.{ }^{*} 6260\right)$ occupying an area of 8,754 ha.

The present study expands the work carried out during the recent mapping of the national park (Vrahnakis et al. 2011) by means of additional phytosociological sampling. Most importantly it reports for the first time the occurrence of the phytosociological order Festuco-Sedetalia acris Tx. 1951 (sensu Dengler 2001 et seq.) and the priority habitat type *6260 (Pannonian sand steppes) in Greece. Therefore, this study specifically aims to describe the floristic composition and ecology of the Greek stands of the Festuco-Sedetalia acris, as well as investigate its differentiation from other dry grassland vegetation types occurring in the same national park. Furthermore, the factors determining the occurrence of this regionally rare habitat type are explored and conservation recommendations are made.

\section{STUDY AREA}

The study area comprised the whole of the Prespa National Park, which is located in northwestern Greece on the frontiers with Albania and the Former Yugoslav Republic of Macedonia. It is characterized by the presence of two lakes, Megali
Prespa and Mikri Prespa at approx. $850 \mathrm{~m}$ a.s.l., while the surrounding mountains of Varnountas (2334 m), Devas (1372 m), Triklario (1750 m) and Vrondero $(1351 \mathrm{~m})$ contribute to the high landscape diversity of the area. The eastern sector of the national park is influenced by the perennial stream of Agios Germanos. The stream was diverted in the 1930s, so as to flow into Lake Megali Prespa instead of Lake Mikri Prespa (Hollis \& Stevenson 1997) (Figure 1). The bedrock is siliceous (mostly granitic) in the eastern part of the national park and calcareous in the western part (I. G. M. E. 1983). Alluvial deposits dominate the plain of the basin, whereas sandy soils are found in the southeastern part of Megali Prespa (Figure 2) and on the Slogi islet (Figure 1). The climate of the area experiences both Mediterranean and continental influences and could be characterized as sub-continental Central European (Ristevski 2000). The mean annual temperature is $10.8{ }^{\circ} \mathrm{C}$ (Meteorological Station of Pretor; period 1961-1991), with the warmest month being July $\left(19.2^{\circ} \mathrm{C}\right)$ and the coldest January $\left(0.2^{\circ} \mathrm{C}\right)$. The mean annual precipitation for that station is $730 \mathrm{~mm}$; in the lower parts of the national park, precipitation ranges from 600 to $700 \mathrm{~mm}$, while in the mountainous zone it increases to 800 $900 \mathrm{~mm}$, and in the higher mountainous areas up to $1400 \mathrm{~mm}$ (Ristevski 2000, Fotiadis et al. 2012).

\section{METHODS}

\subsection{Vegetation data}

The study covers all grassland types within the area of the national park. Field data were sampled during 2009 and 2010 according to the BraunBlanquet method (Braun-Blanquet 1964, Dierschke 1994). The plots were selected subjectively, with the aim of having all different grassland types represented in the data set by an adequate number of relevés, i.e. corresponding roughly to the area covered by each vegetation type. Plots were selected so as to be floristically and ecologically homogeneous, as well as representative of the vegetation type in which they were sampled. Plots were square in shape and had an area of 16-25 $\mathrm{m}^{2}$ each, which is recommended for grasslands (Knapp 1984, Kent \& Coker 1992, Chytrý \& Otýpková 2003). Only vascular plants were recorded. The modified 9-point Braun-Blanquet scale was applied for species cover estimation 


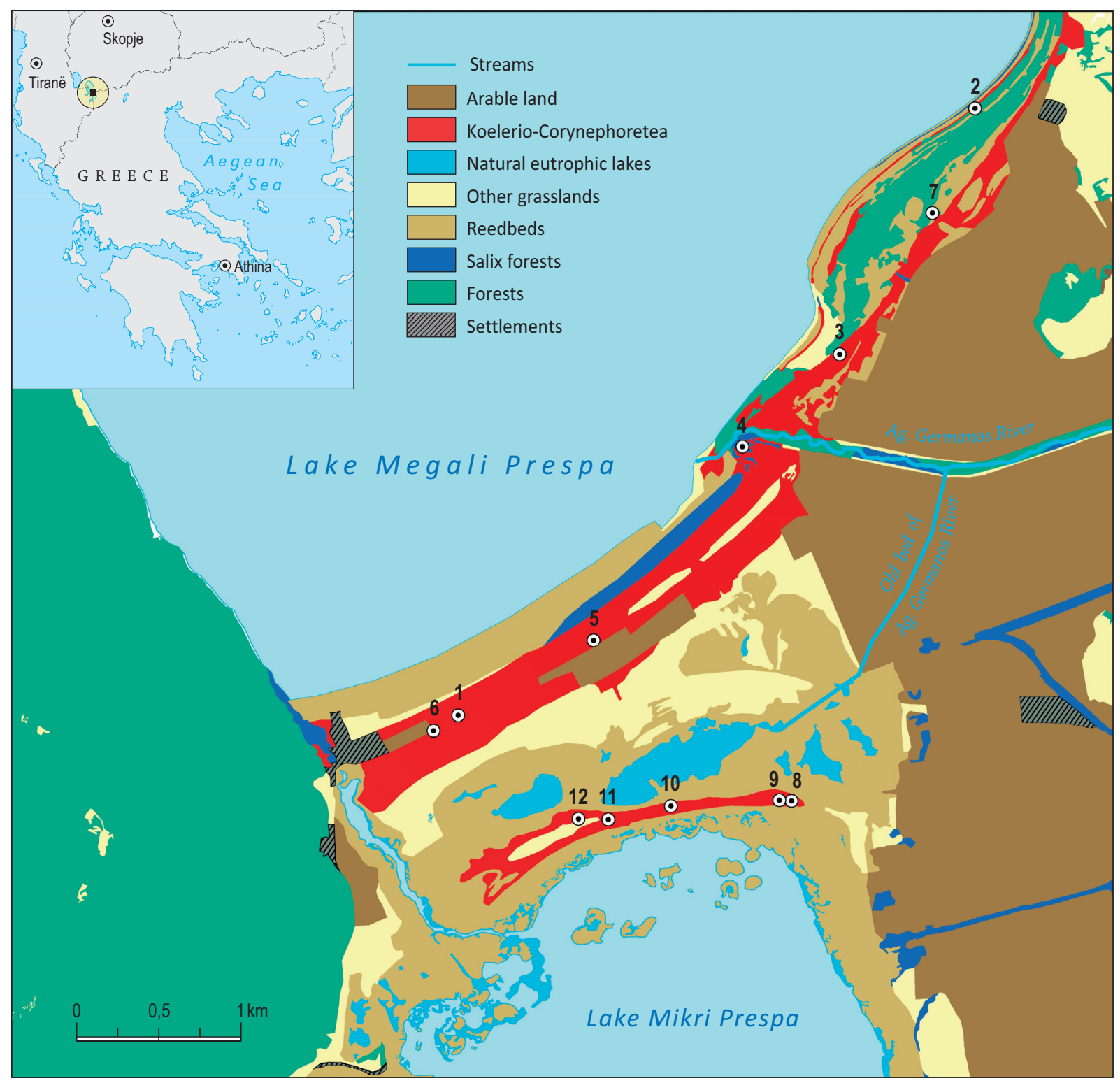

Figure 1: Distribution map of Koelerio-Corynephoretea (red colour) vegetation represented by its relevés (black points) in various localities including the Slogi islet (points 8-12).

Slika 1: Karta razširjenosti vegetacije razreda Koelerio-Corynephoretea (rdeče območje) s predstavljenimi različnimi lokacijami popisov (črne točke), vključno $\mathrm{z}$ otočkom Slogi (točke 8-12).

(Barkman et al. 1964, van der Maarel 1979, Parolly 2003). Besides the floristic data, in each relevé the following parameters were recorded: geological substrate, altitude (in $\mathrm{m}$ a.s.l.), exposition (in degrees), slope inclination (as percentage), total vegetation cover as well as cover of shrub and herb layers (the latter three as an estimate in \%).

In total, 87 relevés of dry grasslands were sampled in the national park, and eight were used from a previous study from the region (Quézel
1969). All relevés are stored in the Balkan Dry Grassland Database (Vassilev et al. 2012), with code EU-00-013 in the Global Index of Vegetation-Plot Databases (GIVD; Dengler et al. 2011). Nomenclature of taxa follows Dimopoulos et al. (2013). The cited syntaxonomy follows Mucina et al. (1993), Mucina (1997), Schaminée et al. (1996), Dengler (2001), Rodwell et al. (2002), Dengler et al. (2003), Berg et al. (2004) and Chytrý (2007). 


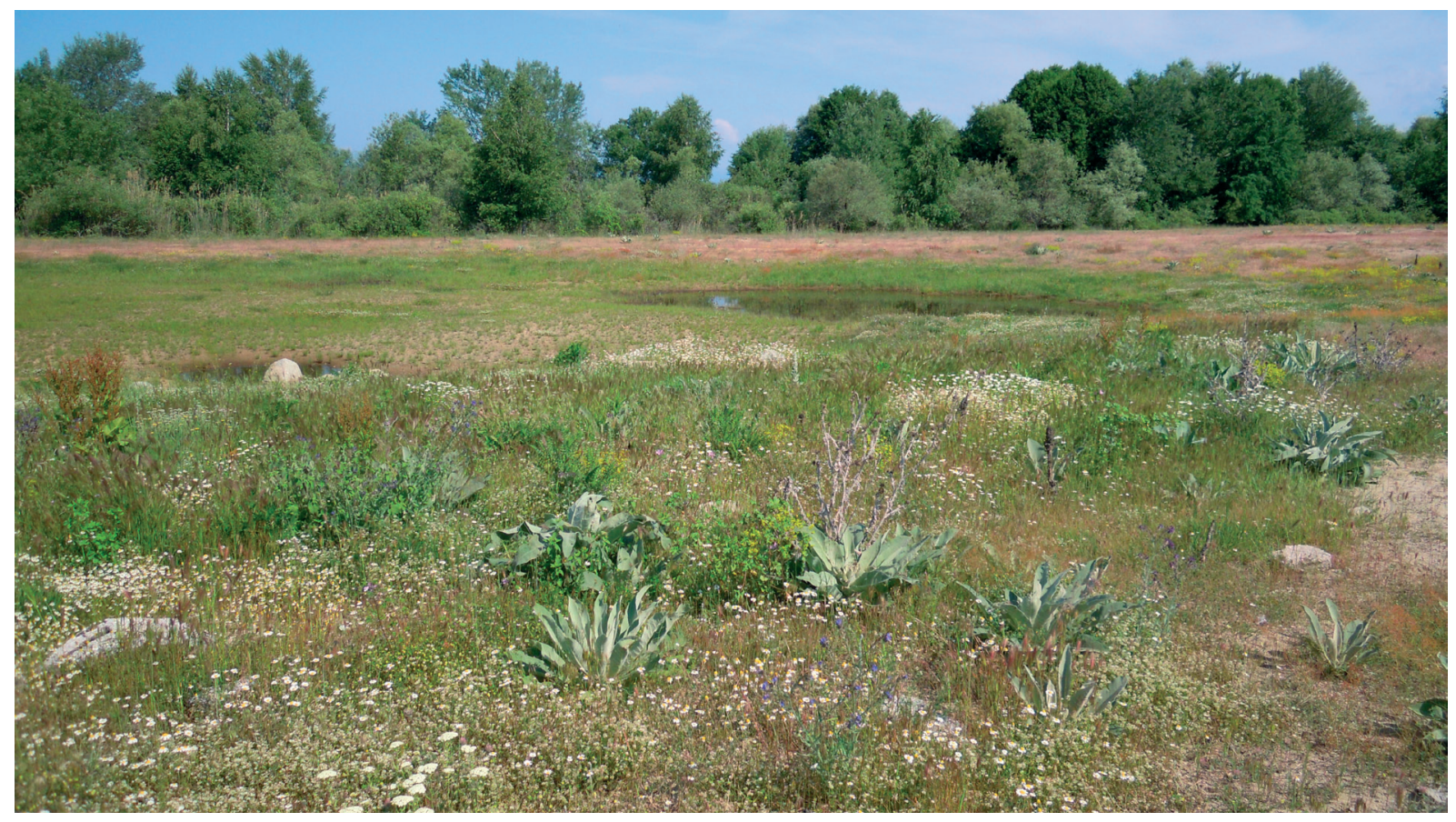

Figure 2: Stand of the Silene frivaldszkyana-Erysimum microstylum (Sileno-Cerastion) community (Koelerio-Corynephoretea) at the shores of Lake Megali Prespa.

Slika 2: Sestoj združbe Silene frivaldszkyana-Erysimum microstylum (Sileno-Cerastion, Koelerio-Corynephoretea) na obali jezera Megali Prespa.

\subsection{NuMERICAL ANALYSES}

The relevés were classified using TWINSPAN (Hill 1979). Three pseudospecies cut-levels $(0 \%$, $5 \%, 25 \%)$ were used, and four levels of divisions were applied. Detrended Correspondence Analysis (DCA) was also applied to facilitate the ecological interpretation of vegetation differentiation, as well as to check the discrimination of the groups produced by the classification. For each relevé, the "relative abundances" of the diagnostic species of six phytosociological classes (Koelerio-Corynephoretea Klika in Klika et Novák 1941, Thero-Brachypodietea Br.-Bl. ex A. de Bolós y Vayreda 1950, Stellarietea mediae R. Tx. et al. ex von Rochow 1951, Festuco-Brometea Br.-Bl. \& Tx. in Br.-Bl. 1949, Daphno-Festucetea Quézel 1964 and Funcetea trifidi Hadač 1946) were calculated according to the assignment in Mucina (1997). As "relative abundances", we used the summed percentage values corresponding to the mid-points of the respective Braun-Blanquet cover-abundance category raised to the power 0.2 . These six classes were used as passive variables in the DCA because they were represented by a significant number of taxa in the data set. This projection al- so aimed at exploring the relationships between the distinguished vegetation units and certain syntaxa (classes) (see Bergmeier et al. 2009).

Furthermore, an additional DCA was applied, using a partial data set in order to better explore the floristic and ecological affinities of the vegetation unit under study with the most closely related vegetation units. In both numerical analyses (classification and ordinations), species cover abundances were square-root transformed.

Diagnostic taxa were determined using the algorithm of Tsiripidis et al. (2009). This algorithm uses a fidelity threshold based on relative constancy differences of taxa between groups. Its advantage in comparison with other numerical means of diagnostic species determination is that it conducts multiple comparisons between different combinations of vegetation groups. Specifically, the algorithm searches in a data set for a group or a combination of groups that is differentiated by a taxon against another group or combination of groups. In this way it can reveal differentiating structures in a data set (Tsiripidis et al. 2009). As the algorithm is based on differences of relative constancy values, the diagnostic taxa resulting from this algorithm were tested 
Table 1: Eigenvalues, length of gradient and total inertia for the DCA axes of the two data sets. Data set A includes all the 95 relevés, while data set B includes the relevés of Koelerio-Corynephoretea, Thero-Brachypodietea and Stellarietea mediae (26 relevés).

Tabela 1: Lastne vrednosti, dolžina gradienta in variabilnost vseh ordinacijskih osi DCA v obeh podatkovnih nizih. Podatkovni niz A vsebuje 95 popisov, niz B pa popise razredov Koelerio-Corynephoretea, Thero-Brachypodietea and Stellarietea mediae (26 popisov).

\begin{tabular}{cccccc}
\hline \multirow{2}{*}{ DATA SET } & \multicolumn{2}{c}{ EIGENVALUES } & \multicolumn{2}{c}{ GRADIENT LENGTH } & TOTAL INERTIA \\
& AXIS 1 & AXIS 2 & AXIS 1 & AXIS 2 & \\
\hline A & 0.726 & 0.477 & 5.847 & 4.153 & 12.242 \\
B & 0.470 & 0.351 & 3.296 & 3.112 & 4.718 \\
\hline
\end{tabular}

with Fisher's exact test. This test compares the absolute constancy of taxa in the group or the groups it differentiates positively, with the one in the groups it differentiates negatively or not differentiating at all. The level of significance chosen in Fisher's exact tests was 0.05. The classification was made using the TWINSPAN algorithm within JUICE ver. 7 (Tichý 2001), and an ordination was carried out with CANOCO ver. 4.5 (ter Braak \& Šmilauer 2002).

\section{RESULT AND DISCUSSION}

\subsection{Classification AND Syntaxonomy}

Six vegetation units of grasslands could be distinguished based on the TWINSPAN classification (Table 2). Specifically, from the eight groups produced at the third level of divisions in TWINSPAN, two pairs of groups were fused to one group each, on the basis of their floristic similarity, as well as the DCA ordination diagrams. In Figure 3 the divisions made by TWINSPAN are presented schematically.

The first unit belongs to Koelerio-Corynephoretea, as easily concluded from the dominance of Koelerio-Corynephoretea diagnostic taxa (see Table 3 ), and it is well differentiated from the other vegetation units of dry grasslands in the study area. The most frequent species in this vegetation unit are Silene conica, Bromus rubens, Cruciata pedemontana, Trifolium arvense, Vulpia myurus, Trifolium arvense and Linaria genistifolia. Most of these species are annuals and diagnostics (according to Mucina 1997, Dengler 2000, Rūsina 2005, Kuzemko 2009) for the subclass Koelerio-Corynephorenea (Klika in Klika \& Novák 1941) Dengler in Dengler et al. 2003 and/or the order Festuco-Sedetalia acris sensu Dengler (2003) of the class Koelerio-Corynephoretea.
Due to the occurrence of Silene conica and Cerastium semidecandrum (diagnostic species of the alliance Sileno conicae-Cerastion semidecandri Korneck 1974 according to Ellenberg (1988), Dengler et al. (2003) and Faust et al. (2011)), as well as the eastern Balkan endemic species Silene frivaldszkyana and Erysimum microstylum, all relevés of the first vegetation unit were classified within the alliance Sileno conicae-Cerastion semidecandri s.l. and named the Silene frivaldszkyana-Eysimum microstylum community. We use here the wide concept of the Sileno conicae-Cerastion semidecan$d r i$, which in the delimitation of Dengler (2001, 2003) includes all the annual-dominated pioneer grasslands on dry calcareous sands in temperate Europe. Dengler $(2001,2003)$ also includes the Bassio laniflorae-Bromion tectorum (Soó 1957)

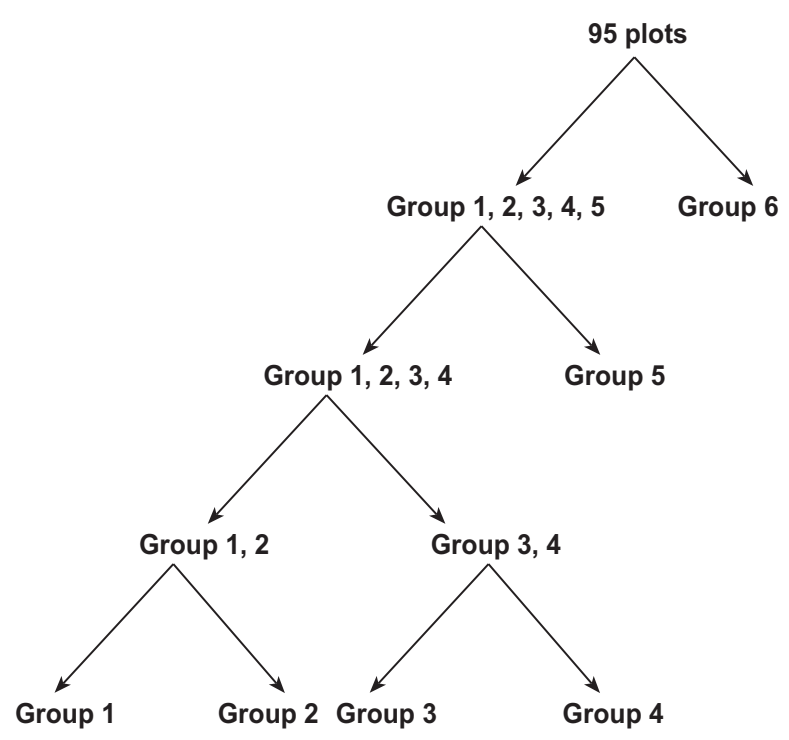

Figure 3: Schematic representation of the divisions made by TWINSPAN.

Slika 3: Shematski prikaz členitve, narejene s programom TWINSPAN. 
Borhidi 1996 in the Sileno-Cerastion s.l., while other authors (e.g. Rodwell et al. 2002) accept it as a separate alliance. According to its authors, the Bassio-Bromion comprises annual-dominated pioneer grasslands of calcareous sands in the Pannonian Basin, thus would be a vicariant alliance to the Sileno-Cerastion s. str. distributed further north and west, and also shows some floristic and ecological similarities to our Silene frivaldszkyanaErysimum microstylum community. Until the justification of two separate vicariant alliances of sub-continental sand pioneer grasslands has been proven and their delimitation established, we prefer to assign our community provisionally to the Sileno conicae-Cerastion semidecandri in the wide sense, which is also supported by the fact that its two eponymous taxa Silene conica and Cerastium semidecandrum are widespread in the stands examined in Prespa National Park.

The alliance Sileno conicae-Cerastion semidecan$d r i$ s.l. is classified within the order Festuco-Sedetalia acris and Koelerio-Corynephorenea subclass of the Koelerio-Corynephoretea class (Dengler 2003, Dengler et al. 2003, Berg et al. 2004). Another syntaxonomical issue is that Pedashenko et al. (2013) report Silene frivaldszkyana from Bulgaria as typical for several alliances of the Festuco-Brometea, but also for the Koelerio-Corynephoretea (in the latter with higher abundance). In Prespa National Park, as already mentioned, Silene frivaldszkyana is found exclusively and with high abundance in the Koelerio-Corynephorenea stands. We therefore decided to classify this vegetation type to a new community, as it is differentiated floristically from all of the associations of the alliance described so far, such as Erodio-Senecionetum vernalis Lührs 1993 and Sileno conicae-Cerastietum semidecandri Korneck 1974 mentioned by Dengler (2000) for Germany, mainly, because it is rich in Balkan endemic taxa.

The Sileno conicae-Cerastion semidecandri s.l. and the Festuco-Sedetalia acris according to the Manual of the European Union Habitats (European Commission 2013) largely correspond to two habitat types, namely *6120 (Xeric sand calcareous grasslands) and *6260 (Pannonic sand steppes). Although our first thoughts were to include the described community in the former habitat type, we have chosen finally to classify it, at least provisionally, to the $* 6260$ habitat type. The reason for this choice is that ${ }^{*} 6120$ has been identified mainly in central and northern Europe (e.g. Germany and Poland (Ödman et al. 2011),
Norway, Sweden (European Commission 2013), Denmark (Silva et al. 2008), Belgium (Demolder et al. 2008)), while *6260 is given for eastern Central Europe (Hungary, Slovakia, Austria and Czech Republic (Šefferova Stanova et al. 2008 and references therein)), but also for Southeast Europe (e.g. Romania (European Commission 2013), Bulgaria (Bulgarian Academy of Sciences 2011) and Serbia (Šefferova Stanova et al. 2008)).

According to Sundseth (2009), complex climatic patterns, formed due to Mediterranean, Carpathian and Alpic influences, cause the Pannonian region to "exhibit a mosaic vegetation structure instead of the more classic zonal arrangements that one sees in other biogeographical regions". Moreover, Metzger et al. (2012) in the environmental stratification of the European continent described the stratum Pannonian 2 (PAN2) of semi-arid plains as having three areas of distribution: one in the middle Danube plain, one in the Black Sea lowlands and one in the Valley of the Struma in Bulgaria and Greece. In this sense, the area of Prespa potentially exhibits a Panonianlike character, at least concerning the vegetation of this specific location (study area).

The second column of the TWINSPAN analysis (Table 2) represents the Thero-Brachypodietea class, since most of the taxa or plant species are diagnostic of the class (e.g. Arenaria leptoclados, Plantago holosteum). It was found in very dry areas of the study area, mostly nearby villages. The class is distinguished from the other classes by annual species, mostly grasses (e.g. Taeniatherum caput-medusae, Aegilops triuncialis, Catapodium rigidum, Lagurus ovatus). The third column represents the Stellarietea mediae class, which is distinguished from the other classes by synanthropic species such as Medicago sativa and M. rigidula, and is dominated by diagnostic taxa of the class, such as Convolvulus arvensis, Cerastium glomeratum, Echium italicum and Geranium molle. It seems that in the study area both classes, Thero-Brachypodietea and Stellarietea mediae, are floristically related to the Koelerio-Corynephoretea, since they mainly represent annual communities affected by human activities.

Columns 4, 5, 6 represent the Festuco-Brometea, Daphno-Festucetea and funcetea trifidi classes, respectively. These three classes are characterized by perennial herbaceous species. The FestucoBrometea is distinguished from other classes by the presence of perennial grasses such as Phleum phleoides and $P$. pratense. In the national park, the 
Festuco-Brometea is represented by several communities, probably of the order Astragalo-Potentilletalia Micevski 1971. These communities are found at intermediate altitudes, on sites with moderate grazing. The Daphno-Festucetea is characterized and well differentiated from the other classes by chamaephytes and spiny species (e.g. Astragalus angustifolius, Morina persica, Eryngium amethystinum, Prunus prostrata). The funcetea trifidi is well differentiated from the other classes by acidophilic grasses, such as Nardus stricta, Deschampsia flexuosa and Alopecurus gerardii (Table 2).

\subsection{Ordination}

The first DCA diagram (Figure 4; Table 1) shows that grasslands of the Koelerio-Corynephoretea in the national park are clearly discriminated from the Festuco-Brometea, Daphno-Festucetea and funcetea trifidi classes. On the other hand, the DCA diagram reveals the floristic affinity of Koelerio-Corynephoretea with the vegetation units of Stellarietea mediae and Thero-Brachypodietea. The first axis in the DCA diagram may represent a moisture gradient, with the driest ecological conditions occurring on the left side of the axis. The second DCA axis mainly represents the geological substrate, with the relevés on siliceous substrates occurring in the lower part of the axis and those on calcareous substrates in the upper part of the axis.

The second DCA diagram (Figure 5) shows a clear floristic differentiation of the grasslands of Koelerio-Corynephoretea from the vegetation of Thero-Brachypodietea and Stellarietea mediae. The first DCA axis in this diagram is related to

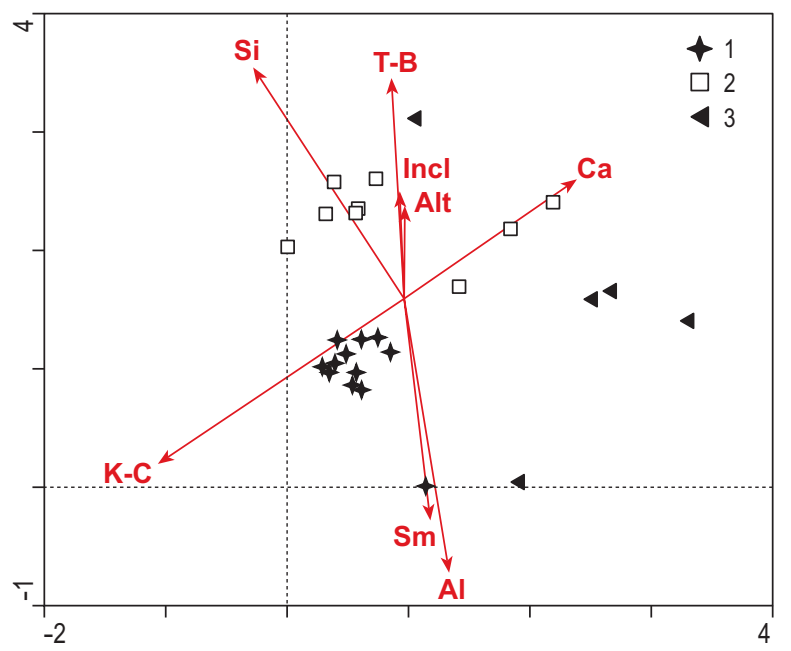

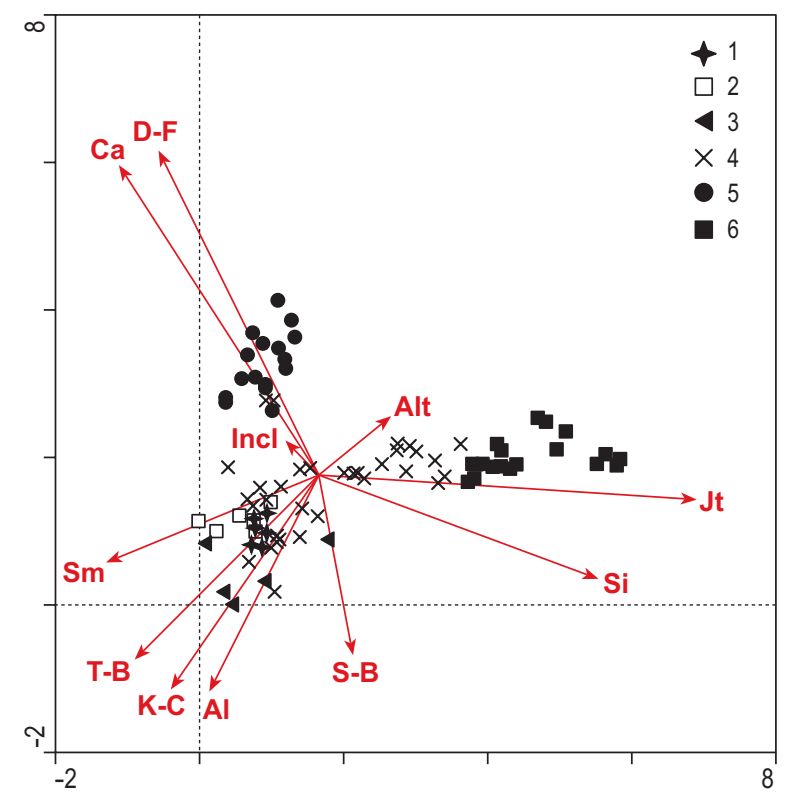

Figure 4: Diagram of all relevés along the first two DCA axes (1: Koelerio-Corynephoretea, 2: Thero-Brachypodietea, 3: Stellarietea mediae, 4: Festuco-Brometea, 5: Daphno-Festucetea, 6: Juncetea trifidi) with explanatory variables passively projected onto the ordination space. The explanatory variables concern the sum per releve of the relative abundances of the species considered as diagnostic of the classes Koelerio-Corynephoretea (K-C), Thero-Brachypodietea (T-B), Stellarietea mediae (Sm), Festuco-Brometea (F-B), Daphno-Festucetea (D-F), Juncetea trifidi (Jt), as well as the environmental variables inclination (Incl), altitude (Alt) and geological substrate (Al: Alluvial, Si: Siliceous, Ca: Calcareous).

Slika 4: Diagram vseh popisov vzdolž prvih dveh DCA osi (1: Koelerio-Corynephoretea, 2: Thero-Brachypodietea, 3: Stellarietea mediae, 4: Festuco-Brometea, 5: Daphno-Festucetea, 6: Juncetea trifidi) z nedovisnimi spremenljivkami, pasivno projeciranimi na ordinacijski prostor. Neodvisne spremenljivke prikazujejo vsoto relativnih abundanc na popis diagnostičnih vrst razredov Koelerio-Corynephoretea (K-C), Thero-Brachypodietea (T-B), Stellarietea mediae (Sm), Festuco-Brometea (F-B), Daphno-Festucetea (D-F), Juncetea trifidi (Jt) in okoljskih spremenljivk: naklon (Incl), višina (Alt) in geološka podlaga (Al: aluvij, Si: silikat, Ca: karbonat).

Figure 5: Diagram of the relevés classified within the classes Koelerio-Corynephoretea (1), Thero-Brachypodietea (2) and Stellarietea mediae (3) with explanatory variables passively projected onto the ordination space. For the abbreviations of explanatory variables see Figure 4.

Slika 5: Diagram popisov, uvrščenih v razrede KoelerioCorynephoretea (1), Thero-Brachypodietea (2) in Stellarietea mediae (3), z neodvisnimi spremenljivkami, pasivno projiciranimi na ordinacijski prostor. Oznake spremenljivk so kot na Sliki 4. 
the calcareous substrate and might additionally reflect a disturbance gradient, as the class Stellarietea mediae contains anthropogenic vegetation units. The second DCA axis is related to the type of substrate (alluvial sands vs. bedrock), as well as with altitude (the relevés of Koelerio-Corynephoretea occur at lower altitudes where the substrate is alluvial). The floristic affinities of the KoelerioCorynephoretea grasslands with those of the Stellarietea mediae have also been documented in other studies. Stroh et al. (2002) recorded that ruderal pioneer communities of Stellarietea mediae have been established after spontaneous succession in sand grasslands belonging to the KoelerioCorynephoretea, while the important role of therophytes in Koelerio-Corynephoretea communities is also supported by Zwaenepoel et al. (2002) and Faust et al. (2011).

\subsection{ECOlOGICAL GHARAGTERISTICS OF THE HABITAT TYPE *6260 IN GREEGE AND CONSERVATION ISSUES}

The occurrence of the ${ }^{*} 6260$ habitat type has been documented mainly from Hungary, but its distribution extends into Lower Austria, Slovakia, Romania and Bulgaria (Šefferova Stanova et al. 2008). The habitat type holds several vegetation types classified in the order Festuco-Sedetalia acris, which represents the subcontinental and continental sand-swards.

It represents dry open grasslands developed on mobile or fixed dunes (alluvial sands, subfossil dune systems) of the Pannonic steppes (European Commission 2013). The sub-continental climate type of the study site, and the sandy shores formed by the active hydrological network in the area offer the two main ecological conditions required for the existence of the ${ }^{*} 6260$ habitat type. Specifically, the Silene frivaldszkyana-Erysimum microstylum [Sileno-Cerastion] community was found on sandy soils on the south-southeastern shores of Lake Megali Prespa (Figure 2) and on the Slogi islet in Lake Mikri Prespa (Figure 1). The altitude of the localities varies from $849 \mathrm{~m}$ a.s.l. (the water level of Megali Prespa was approx. $847 \mathrm{~m}$ a.s.l. during the sampling period of this study) to $855 \mathrm{~m}$ a.s.l. (water level of Mikri Prespa was approx. $854 \mathrm{~m}$ a.s.l.). The sand dunes on the shores of Lake Megali Prespa were formed by the gradual decrease of the water level of the lake over the last 30 years, and partially by me- chanical excavation works for sand extraction at specific localities in recent decades. The sandy islet of Slogi is located 1-2 $\mathrm{m}$ above the water level of Lake Mikri Prespa and probably resulted from historical alluvial deposits of the Agios Germanos River before its anthropogenic diversion to the larger lake. Grasslands of the KoelerioCorynephoretea are distinguished from those of the Stellarietea mediae and Thero-Brachypodietea, because they are found in areas with almost flat and deep alluvial sandy soils (Figure 5).

The stands of the Silene frivaldszkyana-Erysimum microstylum community are highly influenced by the fluctuations of the water levels of the lakes. The high abundance of Scirpoides cf. holoschoenus in this community reveals the influence of underground water on this vegetation unit. Moreover, many ephemeral ponds that are occasionally flooded during winter and spring, especially at the isthmus separating the two lakes, favour the dominance of Azolla filiculoides. Given on the one hand the high susceptibility of the *6260 to degradation due to competition and, on the other hand, the uniqueness of the habitat for Greece, special conservation measures are needed to ensure its continued survival in the area.

In the study area, the major threats to the habitat type are water level fluctuations caused by anthropogenic influences (e.g. excavations, embankments), invasion of non-native species and the absence of grazing. We assume that any further increase in the water level of the lakes will negatively affect the *6260 habitat type in the study area. However, detailed studies are needed to define a sustainable water level to maintain a balance between safeguarding the habitat type and meeting the irrigation needs of local farmers.

The existence of short, shrub-like trees of $S a$ lix alba as well as of trees like Robinia pseudoacacia and Morus spp., planted at the localities of the habitat type, may be a threat because of the possible invasion of these species in the habitat. The invasion of Robinia pseudoacacia has been recorded as a serious threat for ${ }^{*} 6260$ in Slovakia (Šefferova Stanova et al. 2008). This species, due to its intensive vegetative spread and its high germination rates after fire, becomes a superior competitor in secondary succession processes. Systematic eradication of such invasive trees is suggested for the study area by means of mechanical cleaning (cutting), subsequent grazing of surviving shoots and monitoring of its regeneration (Kelemen \& Warner 1996). 
The soil surface of the stands of the community is often covered by a conspicuous cryptogam layer (e.g. lichens of the genus Cladonia and xerophytic mosses of the genus Tortula s.l.), which is typical for the habitat type in general (Šefferova Stanova et al. 2008). Such relation of inland dunes and dense moss layers has already been indicated for ecologically similar habitat types (e.g. for *6120 by Ödman et al. (2011)). The study area is only occasionally grazed by cattle. Abandonment of grazing may lead to closed grasslands and increased moss cover (Molnár 2003). Animal trampling can prevent the formation of dense moss carpets. However overgrazing must be avoided, as this will enrich the sand with nutrients, facilitating the occurrence of some diagnostic species of Stellarietea mediae or Molinio-Arrhenatheretea, such as Plantago lanceolata. On the other hand, the cessation of grazing on sand dunes is expected to cause increased biomass production and subsequently higher litter and humus accumulation. Such changes will further favour generalists and may cause the local extinction of some open sand grassland species (Onodi et al. 2006). It has been reported that grasslands suitable for open Pannonic sand steppes in Hungary turn to weedy fields due to grassland abandonment (Török et al. 2000). Consequently, a proper stocking rate must be estimated and maintained in the study area for conservation purposes.

\section{CONCLUSIONS}

This paper reports the southernmost occurrence of the priority habitat type *6260 "Pannonic sand steppes" in the Balkan Peninsula, from sandy soils at the south-southeastern shores of Lake Megali Prespa and on the Slogi islet in Lake Mikri Prespa, in the Prespa National Park of Greece. The prevailing sub-continental climate, the gradual drop of the water level of Lake Megali Prespa over the past few decades, the alluvial deposits of the river Agios Germanos in Lake Mikri Prespa and, to some extent, mechanical excavation works on the shores of Lake Megali Prespa in recent decades are considered as factors that positively influenced this habitat type.

Syntaxonomically, the stands are classified as Silene frivaldszkyana-Erysimum microstylum community within the alliance Sileno conicae-Cerastion semidecandri s.l. (including Bassio laniflorae-Bromion tectorum), the order Festuco-Sedatalia acris (= continental grasslands of base-rich, nutrient-poor sands) and the class Koelerio-Corynephoretea. One of the most important factors for the sustainability of the habitat type is grazing; undergrazing will probably lead to the dominance of moss carpets, which is a typical feature of the habitat type under no vegetation management, while overgrazing will affect vegetation by increasing nutrient content of the soils, which will probably favour the invasion of diagnostic species of Stellarietea mediae or Molinio-Arrhenatheretea. Finally, the control of the water level against rising in Lake Mikri Prespa is considered crucial since this will probably favour the invasion of species such as Phragmites australis and Azolla filiculoides that would eventually alter the vegetation type. In Lake Megali Prespa the water level cannot be artificially controlled, but the areas occupied by the habitat type do not appear threatened by a potential water level rise as they lie 3-5 $\mathrm{m}$ above the present water level. Finally, the spread of "aggressive" trees, like Robinia pseudoacacia, from plantations must be controlled.

\section{ACKNOWLEDGMENTS}

The research was partly financed by the project "Record, Assessment and Geographical Presentation of the Range and Forest Habitat Types of the Natura 2000 Sites Prespa National Park (Ethnikos Drymos Prespon-GR 1340001), Mt. Varnountas (Ori Varnountas-GR 1340003) and Adjacent Areas", managed by the Society for the Protection of Prespa. We thank Dr. Jürgen Dengler and three anonymous reviewers for their constructive comments in improving the manuscript. Finally, we thank Laura Sutcliffe (Göttingen) for linguistic editing and EDGG for covering the costs of this with an IAVS grant.

\section{REFERENCES}

Barkman, J., Doing, H. \& Segal, S. 1964: Kritische Bemerkungen und Vorschläge zur quantitativen Vegetationsanalyse. Acta Botanica Neerlandica 13: 394-419.

Berg, C., Dengler, J., Abdank, A. \& Isermann, M. (eds.) 2004: Die Pflanzengesellschaften Mecklenburg-Vorpommerns und ihre Gefährdung. Textband. Weissdorn, Jena, 606 pp. 
Bergmeier, E., Konstantinou, M., Tsiripidis, I. \& Sykora, K. V. 2009: Plant communities on metalliferous soils in northern Greece. Phytocoenologia 39: 411-438.

Boch, S. \& Dengler, J. 2006: Floristische und ökologische Charakterisierung sowie Phytodiversität der Trockenrasen auf der Insel Saaremaa (Estland). Arbeiten aus dem Institut für Landschaftsökologie Münster 15: 55-71.

Borhidi, A., Kevey, B. \& Varga, Z. 2001: Checklist of the higher syntaxa of Hungary. Annals of Botany (N. S.) 1: 159-166.

Braun-Blanquet, J. 1964: Pflanzensoziologie. Grundzüge der Vegetationskunde. 3rd. ed. Springer, Wien, 865 pp.

Bulgarian Academy of Sciences. 2011: Red Data Book of the Republic of Bulgaria-Digital edition. Published on the Internet: http://e-ecodb. bas.bg/rdb/en/vol3 [accessed 31/10/2013].

Chytrý, M. \& Otýpková, Z. 2003: Plot sizes used for phytosociological sampling of European vegetation. Journal of Vegetation Science 14: 563-570.

Chytrý, M. (ed.) 2007: Vegetation of the Czech Republic-1. Grassland and heathland vegetation [in Czech, with English summaries]. Academia, Praha, 526 pp.

Dafis, S., Papastergiadou, E., Lazaridou, T. \& Tsiafouli, M. 2001: Technikos Odigos Anagnorisis, Perigrafis kai Chartografisis Tipon Oikotopon tis Elladas (Technical guide for identification, description and mapping of habitat types of Greece). Greek Wetland and Biotope Centre (EKBY), Thessaloniki, 908 pp.

Demolder, H., Delescaille, L. M., Van Landuyt, W., Wouters J., Van Looy, K. \& Paelinckx, D. 2008: Conservation status of the Natura 2000 habitat 6120 (Xeric sand calcareous grasslands) for the Belgian Atlantic region. In: Paelinckx D., Van Landuyt W. \& De Bruyn L. (eds.): Conservation status of the Natura 2000 habitats and species. Report of the Research Institute for Nature and Forest, INBO. R. 2008. 15, Brussels, pp. 1-4.

Dengler, J. 2000: Synsystematische Stellung und Gliederung deruckermärkischen Sandtrockenrasen. Berichte der Naturwissenschaftlichen Gesellschaft Bayreuth 24: 302-306.

Dengler, J. 2001: Erstellung und Interpretation synchorologischer Karten am Beispiel der Klasse Koelerio-Corynephoretea. Berichte der Reinhold-Tüxen-Gesellschaft 13: 223-228.

Dengler, J. 2003: Entwicklung und Bewertung neuer Ansätze in der Pflanzensoziologie unter besonderer Berücksichtigung der Vegetationsklassifikation. Archiv Naturwissenschaftlicher Dissertationen 14: 1-297.

Dengler, J., Berg, C., Eisenberg, M., Isermann, M., Jansen, F., Koska, I., Löbel, S., Manthey, M., Päzolt, J., Spangenberg, A., Timmermann, T. \& Wollert, H. 2003: New descriptions and typifications of syntaxa within the project "Plant communities of MecklenburgVorpommern and their vulnerability". Part I. Feddes Repertorium 114: 587-631.

Dengler, J., Jansen, F., Glöckler, F., Peet, R. K., De Cáceres, M., Chytrý, M., Ewald, J., Oldeland, J., Lopez-Gonzalez, G., Finckh, M., Mucina, L., Rodwell, J. S., Schaminée, J. H. J. \& Spencer, N. 2011: The Global Index of Vegetation-Plot Databases (GIVD): a new resource for vegetation science. Journal of Vegetation Science 22: 582-597.

Dierschke H. 1994: Pflanzensoziologie-Grundlagen und Methoden. Ulmer, Stuttgart, 683 pp.

Dimopoulos, P., Raus, T., Bergmeier E., Constantinidis, T., Iatrou G., Kokkini, S., Strid, A. \& Tzanoudakis, D. 2013: Vascular Plants of Greece. An annotated checklist. Botanic Garden and Botanical Museum Berlin-Dahlem \& Hellenic Botanical Society, Berlin \& Athens, $372 \mathrm{pp}$.

Doniță, N., Popescu, A., Paucă-Comănescu, M., Mihăilescu, S. \& Biriş, I. A. 2005: Habitele din România. Edit. Tehnică Silvică, Bucureşti, 500 pp.

Ellenberg, H. 1988: Vegetation Ecology of Central Europe, $4^{\text {th }}$ ed. University of Cambridge, Cambridge, 705 pp.

European Commission. 2013: Interpretation Manual of European Union Habitats. European Union, Bruxelles, 146 pp.

Faust, C., Süss, K., Storm, C. \& Schwabe, A. 2011: Threatened inland sand vegetation in the temperate zone under different types of abiotic and biotic disturbances during a tenyear period. Flora 206: 611-621.

Fotiadis, G., Angelova, N., Nikolov, N., Melovski, Lj., Karadelev, M., Avukatov, V. \& Nikolov, L. 2012: Conservation Action Plan for Grecian Juniper Forests in the Prespa Lakes Watershed (Final Report). UNDP/GEF project "Integrated ecosystem management in the Prespa lakes basin", F. Y. R. of Macedonia, Skopje, 46 pp.

Hill, M. O. 1979: TWINSPAN - a FORTRAN program for arranging multivariate data in an 
ordered two-way table by classification of the individuals and the attributes. Ecology \& Systematics, Cornell University, Ithaca, NY, $45 \mathrm{pp}$.

Hollis, G. E. \& Stevenson, A. C. 1997: The physical basis of the lake Mikri Prespa systems: geology, climate, hydrology and water quality. Hydrobiologia 351: 1-19.

I. G. M. E. [Institute of Geology and Mineralogy Research] 1983: Geologikos Chartis tis Elladas (Geological Map of Greece), scale $1: 500.000$. Athens.

Kelemen, J. \& Warner, P. 1996: Nature Conservation Management of Grasslands in Hungary. Summary. Conservation Handbook Series of the Hungarian National Authority for Nature Conservation, Budapest, 39 pp.

Kent, M. \& Coker, P. 1992: Vegetation description and analysis. A practical approach. John Wiley, London, $336 \mathrm{pp}$.

Knapp, R. 1984: Sample (relevé) areas (distribution, homogeneity, size, shape) and plot-less sampling. In: Knapp, R. (ed.), Handbook of Vegetation Science 4. Junk, The Hague, pp. 101-119.

Kuzemko, A. 2009: Dry grasslands on sandy soils in the forest and forest-steppe zones of the plains part of Ukraine: present state of syntaxonomy. Tuexenia 29: 369-390.

Laime, B. \& Tjarve, D. 2009: Grey dune plant communities (Koelerio-Corynephoretea) on the Baltic coast in Latvia. Tuexenia 29: 409-435.

Löbel, S. \& Dengler, J. 2007: Dry grasslands communities on southern Öland: phytosociology, ecology, and diversity. Acta Phytogeographica Suecica 88: 13-31.

Matuszkiewicz, W. 2008: Przewodnik do oznaczania zbiorowisk roślinnych Polski. Wydawnictwo Naukowe PWN, Warszawa, 537 pp.

Metzger, M. J., Shkaruba, A. D., Jongman, R. H. G. \& Bunce, R. G. H. 2012: Descriptions of the European Environmental Zones and Strata. Alterra Report 2281. Wageningen, $154 \mathrm{pp}$.

Molnár Z. (eds.) 2003. Dry sand vegetation of the Kiskunsag. Termeszet BUVAR Alapitvany Kiado, Budapest, 30 pp.

Mucina, L., Grabherr, G. \& Ellmauer, T. (eds.) 1993: Die Pflanzengesellschaften Österreichs. Teil I: Anthropogene Vegetation. Fischer, Jena, $578 \mathrm{pp}$.

Mucina, L. 1997: Conspectus of classes of European vegetation. Folia Geobotanica et Phytotaxonomica 32: 117-172.
Ödman, A. M., Mårtensson, L.-M., Sjöholm, C. \& Olsson, P. A. 2011: Immediate responses in soil chemistry, vegetation and ground beetles to soil perturbation when implemented as a restoration measure in decalcified sandy grassland. Biodiversity and Conservation 20: 3039-3058.

Onodi, G., Kertesz, M. \& Botta-Dukat, Z. 2006: Effects of simulated grazing on open perennial sand grassland. Community Ecology 7: 133-141.

Parolly, G. 2003: Towards common standards in phytosociological papers submitted to the Turkish Journal of Botany: A Letter from the Editor. Turkish Journal of Botany 27: 163-165.

Pedashenko, H., Apostolova, I., Boch, S., Ganeva, A., Janišová, M., Sopotlieva, D., Todorova, S., Ünal, A., Vassilev, K., Velev, N. \& Dengler, J. 2013: Dry grasslands of NW Bulgarian mountains: first insights into diversity, ecology and syntaxonomy. Tuexenia 33: 309-346.

Quézel, P. 1969: La vegetation du massif de Bela Voda (Macedoine Nord-Occidentale). Biologia Gallo-Hellenica 2: 91-112.

Ristevski, P. 2000: Climatic and Agroclimatic Characteristics in the Prespa Lake Basin. International Symposium-Sustainable Development of Prespa Region, Oteševo, pp. 212-223.

Rodwell, J. S., Schaminée, J. H. J., Mucina, L., Pignatti, S., Dring, J. \& Moss, D. 2002: The diversity of European vegetation-An overview of phytosociological alliances and their relationships to EUNIS habitats. Rapp. EC-LNV 2002 (054): National Reference Centre for Agriculture, Nature and Fisheries, Wageningen, $168 \mathrm{pp}$.

Rūsina, S. 2005: Diagnostic species of mesophylous and xerophylous grassland plant communities in Latvia. Latvijas Universitates Raksti 685: 69-95.

Schaminée, J. H. J., Stortelder, A. H. F., Weeda, E. J. (eds.) 1996: De Vegetatie von NederlandDeel 3. Plantengemeenschappen van graslanden, zomen en droge heiden. Opulus, Uppsala, $360 \mathrm{pp}$.

Šefferova Stanova, V., Vajda, Z. \& Janak, M. 2008: Management of Natura 2000 habitats. 6260 *Pannonic sand steppes. European Commission, Bruxelles, $24 \mathrm{pp}$.

Silva, J. P., Toland, J., Jones, W., Eldridge, J., Thorpe, E. \& O'Hara, E. 2008: LIFE and Europe's grasslands: Restoring a forgotten habitat. European Commission, 56 pp. 
Stroh, M., Storm, C., Zehm, A. \& Schwabe, A. 2002: Restorative grazing as a tool for directed succession with diaspore inoculation: the model of sand ecosystems. Phytocoenologia 32: 595-625.

Sundseth, K. 2009: Natura 2000 in the Pannonian Region. European Commission, 12 pp.

ter Braak, C. J. F. \& Šmilauer, P. 2002: CANOCO Reference Manual and CanoDraw for Windows User's Guide: Software for Canonical Community Ordination (version 4.5). Microcomputer Power, Ithaca, $351 \mathrm{pp}$.

Tichý, L. 2001: JUICE, software for vegetation classification. Journal of Vegetation Science 13: 451-453.

Török, K., Szili-Kovacz, T., Halassy, M., Toth, T., Hayek, Z., Paschke, M. W. \& Wardell, L. J. 2000: Immobilization of soil nitrogen as a possible method for the restoration of sandy grassland. Applied Vegetation Science 3: 7-14.

Tsiripidis, I., Bergmeier, E., Fotiadis, G. \& Dimopoulos, P. 2009: A new algorithm for the determination of differential taxa. Journal of Vegetation Science 20: 233-240.

van der Maarel, E. 1979: Transformation of cover-abundance values in phytosociology and its effect on community similarity. Vegetatio 39: 97-114.

Vassilev, K., Stevanović Dajić, Z., Ćušterevska, R., Bergmeier, E. \& Apostolova, I. 2012: Balkan Dry Grasslands Database. In: Dengler J., Oldeland J., Jansen F., Chytrý M., Ewald J., Finckh M., Glöckler F. Lopez-Gonzalez G, Peet R. K., Schaminée J. H. J., Vegetation databases for the $21^{\text {st }}$ century. Biodiversity \& Ecology 4: 330-330.
Vicherek, J. 1972: Die Sandpflanzengesellschaften des unteren und mittleren Dnjeprstromgebietes (die Ukraine). Folia Geobotanica et Phytotaxonomica 7: 9-46.

Vrahnakis, M., Fotiadis, G. \& Kazoglou, Y. 2011: Katagrafi, Aksiologisi kai Geografiki Apotiposi ton Livadikon kai Dasikon Tipon Oikotopon ton Periochon tou Diktiou Phisi 2000: (Ethnikos Drymos Prespon - GR 1340001), Mt. Varnountas (Ori Varnountas - GR 1340003) kai periochon periks auton (Registration, Assessment and Geographical Representation of the Range and Forest Habitat Types of the Natura 2000 Sites Prespa National Park (Ethnikos Drymos Prespon - GR 1340001), Mt. Varnountas (Ori Varnountas GR 1340003) and Adjusted Areas) - Final Report. TEI of Larissa, Society for the Protection of Prespa, 107 pp. + annexes.

Zwaenepoel, A., T'Jollyn, F., Vandenbussche, V. \& Hoffmann, M. 2002: Systematiek van natuurtypen voor Vlaanderen: 6.2 Graslanden, Droge graslanden. Verslag van het Instituut voor Natuurbehoud, Bruxelles, $21 \mathrm{pp}$.

Received: 27. 2. 2013

Accepted: 8. 3. 2014

Co-ordinating editor: Jürgen Dengler 
Table 2: Constancy synoptic table of the differential taxa of the six dry grassland vegetation units. Dark grey color indicates positive differentiation, medium grey color indicates positive-negative differentiation, white color and italic letters indicates negative differentiation and light grey color indicates non-differentiation (see Tsiripidis et al. 2009); 1: overall constancy, 2: Koelerio-Corynephoretea, 3: Thero-Brachypodietea, 4: Stellarietea mediae, 5: FestucoBrometea, 6: Daphno-Festucetea, 7: Juncetea trifidi. Only species with statistically higher constancy (Fisher's exact test; $\alpha=0.05$ ) in the groups that differentiate positively vs. those that differentiate negatively or not differentiating at all are presented as differential. Species with a constancy lower than $20 \%$ in any column, and companion species with overall constancy lower than $10 \%$, have been omitted.

Tabela 2: Sinoptična tabela s stalnostjo razlikovalnih taksonov šestih vegetacijskih tipov suhih travišč. Temno siva barva prikazuje pozitivno razlikovanje, srednje siva barva nakazuje pozitivno-negativno razlikovanje, bela barva in poševna pisava nakazujeta negativno razlikovanje in svetlo siva barva označuje nobenega razlikovanja (Tsiripidis et al. 2009); 1: celotna stalnost, 2: Koelerio-Corynephoretea, 3: Thero-Brachypodietea, 4: Stellarietea mediae, 5: FestucoBrometea, 6: Daphno-Festucetea, 7: Juncetea trifidi. Samo vrste s statistično visoko stalnostjo (Fisherjev natančni test; $\alpha=0.05)$ v skupinah, ki se pozitivno razlikujejo napram tistim, ki se razlikujejo negativno ali sploh ne, so prikazane kot razlikovalne. Vrste s stalnostjo, manjšo od $20 \% \mathrm{v}$ enem stolpcu in spremljevalke s celotno stalnostjo, manjšo od $10 \%$, niso prikazane.

\begin{tabular}{|c|c|c|c|c|c|c|c|}
\hline Vegetation unit & 1 & 2 & 3 & 4 & 5 & 6 & 7 \\
\hline Number of relevés & 95 & 12 & 9 & 5 & 35 & 14 & 20 \\
\hline $\begin{array}{l}\text { Geology (Sa: sandy, Al: alluvial, } \\
\text { Si: siliceous, Ca: calcareous) }\end{array}$ & & $\mathrm{Sa}$ & $\mathrm{Si}, \mathrm{Ca}, \mathrm{Al}$ & $\mathrm{Al}$ & $\mathrm{Si}, \mathrm{Ca}, \mathrm{Al}$ & $\mathrm{Ca}$ & $\mathrm{Si}$ \\
\hline Mean altitude (m a.s.1.) & & 853 & 987 & 976 & 1300 & 1490 & 1900 \\
\hline Altitudinal range (m a.s.1.) & & $848-857$ & $850-1110$ & $850-1260$ & $850-1940$ & $1310-1760$ & $1730-2060$ \\
\hline Mean number of taxa per relevé & 33 & 43.7 & 44.0 & 28.0 & 34.0 & 43.5 & 24.0 \\
\hline \multicolumn{8}{|l|}{ Differential species $(p<0.01)$} \\
\hline Silene frivaldskyana & 13 & 100 & . & . & . & . & . \\
\hline Euphorbia baselicis & 9 & 75 & . & 20 & . & . & . \\
\hline Scirpoides cf. holoschoenus & 9 & 75 & . & . & . & . & . \\
\hline Cruciata pedemontana & 24 & 100 & 22 & 40 & 17 & 7 & . \\
\hline Hypericum perforatum & 19 & 83 & 22 & 20 & 14 & . & . \\
\hline Torilis arvensis & 18 & 75 & 11 & 20 & 6 & 29 & . \\
\hline Draba muralis & 17 & 67 & 11 & 20 & 17 & . & . \\
\hline Delphinium balcanicum & 8 & 58 & . & . & . & 7 & . \\
\hline Medicago minima & 12 & 42 & 11 & 20 & 9 & 7 & . \\
\hline Papaver rhoeas & 6 & 42 & . & . & 3 & . & . \\
\hline Verbascum cf. eriophorum & 7 & 42 & 11 & . & . & 7 & . \\
\hline Vicia lathyroides & 9 & 42 & 11 & . & 9 & . & . \\
\hline Linaria genistifolia subsp. sofiana & 18 & 92 & . & 40 & 11 & . & . \\
\hline Jasione heldreichii & 19 & 67 & . & . & 14 & . & 25 \\
\hline Tordylium maximum & 11 & 42 & . & . & 6 & 21 & . \\
\hline Silene conica & 36 & 100 & 100 & . & 23 & 36 & . \\
\hline Bromus rubens & 27 & 100 & 100 & . & 14 & . & . \\
\hline Erysimum microstylum & 31 & 92 & 67 & 20 & 20 & 29 & . \\
\hline Poa bulbosa & 59 & 92 & 100 & 40 & 63 & 64 & 15 \\
\hline Filago arvensis & 27 & 75 & 100 & . & 20 & 7 & . \\
\hline Centaurea cuneifolia & 17 & 75 & 33 & 20 & 9 & . & . \\
\hline Herniaria incana & 16 & 50 & 44 & . & 14 & . & . \\
\hline Petrorhagia saxifraga & 18 & 50 & 44 & . & 14 & 14 & . \\
\hline Aira elegantissima & 12 & 42 & 22 & . & 11 & . & . \\
\hline Stachys angustifolia & 7 & 33 & 22 & . & 3 & . & . \\
\hline Hypericum olympicum & 17 & 42 & 33 & . & 17 & 14 & . \\
\hline Trifolium hirtum & 21 & 42 & 100 & . & 17 & . & . \\
\hline Trifolium arvense & 41 & 92 & 100 & 20 & 46 & 14 & . \\
\hline
\end{tabular}




\begin{tabular}{|c|c|c|c|c|c|c|c|}
\hline Vegetation unit & 1 & 2 & 3 & 4 & 5 & 6 & 7 \\
\hline Thymus sibthorpii & 58 & 75 & 67 & 40 & 77 & 21 & 40 \\
\hline Astragalus onobrychis & 29 & 75 & 44 & . & 40 & 7 & . \\
\hline Cerastium brachypetalum subsp. roeseri & 14 & 25 & 44 & . & 3 & 36 & . \\
\hline Avena sterilis & 27 & 92 & 100 & 40 & 11 & . & . \\
\hline Cichorium intybus & 14 & 42 & 22 & 40 & 11 & . & . \\
\hline Alyssum chalcidicum & 9 & 25 & 33 & 20 & 6 & . & . \\
\hline Convolvulus cantabrica & 9 & 25 & 33 & 20 & 6 & . & . \\
\hline Anchusa officinalis & 18 & 83 & 11 & 40 & 11 & . & . \\
\hline Eryngium campestre & 53 & 100 & 100 & 60 & 66 & 21 & . \\
\hline Vulpia myurus & 29 & 75 & 44 & 40 & 37 & $\cdot$ & . \\
\hline Potentilla argentea & 15 & 25 & 11 & 20 & 26 & . & . \\
\hline Bromus hordeaceus & 44 & 100 & 100 & 40 & 37 & 43 & . \\
\hline Sanguisorba minor & 40 & 83 & 67 & 20 & 49 & 29 & . \\
\hline Achillea coarctata & 27 & 58 & 56 & 40 & 26 & 21 & . \\
\hline Bromus squarrosus & 24 & 58 & 33 & 20 & 23 & 29 & . \\
\hline Trifolium scabrum & 35 & 50 & 33 & 20 & 51 & 36 & . \\
\hline Sedum acre & 23 & 42 & 56 & 20 & 20 & 29 & . \\
\hline Galium verum subsp. verum & 26 & 67 & 11 & . & 23 & 57 & . \\
\hline Melica ciliata & 16 & 42 & 22 & . & 9 & 36 & . \\
\hline Anthemis arvensis subsp. arvensis & 18 & 42 & . & 20 & 17 & 36 & . \\
\hline Dasypyrum villosum & 29 & 33 & 100 & . & 23 & 50 & . \\
\hline Trifolium campestre & 29 & 25 & 44 & . & 37 & 50 & 5 \\
\hline Euphorbia myrsinites & 46 & 83 & 67 & . & 40 & 100 & . \\
\hline Rumex acetosella & 51 & 100 & 33 & 40 & 40 & . & 85 \\
\hline Centaurea alba & 13 & 8 & 22 & 40 & 20 & . & . \\
\hline Hordeum murinum & 11 & . & 56 & 60 & 6 & . & . \\
\hline Sedum caespitosum & 11 & $\cdot$ & 44 & 40 & 11 & $\cdot$ & . \\
\hline Cynosurus echinatus & 28 & 17 & 89 & 60 & 29 & 21 & 5 \\
\hline Echium italicum & 7 & 8 & 22 & 40 & 6 & . & . \\
\hline Anthemis cretica subsp. carpatica & 14 & . & 22 & . & 29 & . & 5 \\
\hline Bellardia latifolia & 14 & 8 & 33 & . & 26 & . & . \\
\hline Chamaecytisus eriocarpus & 26 & . & 22 & . & 46 & . & 35 \\
\hline Dactylis glomerata & 17 & . & 33 & . & 26 & 29 & $\cdot$ \\
\hline Xeranthemum annuum & 17 & . & 22 & . & 23 & 43 & . \\
\hline Crepis sancta & 20 & 8 & 44 & . & 29 & 29 & . \\
\hline Crupina vulgaris & 27 & . & 100 & . & 20 & 71 & . \\
\hline Arenaria leptoclados & 32 & . & 100 & 20 & 29 & 71 & . \\
\hline Festuca valesiaca & 39 & 8 & 33 & . & 57 & 43 & 35 \\
\hline Taeniatherum caput-medusae & 16 & 33 & 67 & 20 & 6 & 14 & $\cdot$ \\
\hline Convolvulus elegantissimus & 11 & . & 78 & 20 & 6 & $\cdot$ & . \\
\hline Plantago holosteum & 11 & . & 67 & $\cdot$ & 9 & . & 5 \\
\hline Aegilops triuncialis & 14 & . & 56 & 20 & 17 & 7 & . \\
\hline Trifolium glomeratum & 4 & . & 33 & . & 3 & . & . \\
\hline Catapodium rigidum & 3 & . & 33 & . & . & . & . \\
\hline Lagurus ovatus & 3 & . & 33 & . & . & . & . \\
\hline Medicago orbicularis & 4 & $\cdot$ & 33 & . & 3 & . & . \\
\hline Convolvulus arvensis & 6 & 17 & . & 60 & 3 & . & . \\
\hline $\begin{array}{l}\text { Tragopogon porrifolius subsp. } \\
\text { eriospermus }\end{array}$ & 7 & 17 & . & 60 & 6 & . & . \\
\hline Medicago rigidula & 8 & . & 11 & 60 & 9 & 7 & . \\
\hline Medicago sativa & 8 & . & 11 & 60 & 9 & 7 & . \\
\hline Centaurea salonitana & 11 & . & 11 & 20 & 9 & 36 & . \\
\hline
\end{tabular}




\begin{tabular}{|c|c|c|c|c|c|c|c|}
\hline Vegetation unit & 1 & 2 & 3 & 4 & 5 & 6 & 7 \\
\hline Agrostis canina & 18 & . & . & 20 & 14 & . & 55 \\
\hline Pilosella leucopsilon & 33 & . & . & 20 & 43 & . & 75 \\
\hline Trisetum flavescens & 16 & . & . & 20 & 23 & 7 & 25 \\
\hline Bromus sterilis & 14 & 17 & . & 40 & 26 & . & . \\
\hline Plantago lanceolata & 20 & 17 & 22 & 60 & 31 & 7 & . \\
\hline Verbascum longifolium & 12 & . & 11 & 20 & 23 & . & 5 \\
\hline Hypericum barbatum & 23 & . & . & . & 26 & 7 & 60 \\
\hline Phleum phleoides & 13 & . & . & . & 29 & 14 & . \\
\hline Armeria canescens & 12 & . & 11 & . & 26 & . & 5 \\
\hline Phleum pratense & 7 & . & . & . & 20 & . & . \\
\hline Juniperus oxycedrus subsp. oxycedrus & 9 & . & 11 & . & 23 & . & . \\
\hline Centaurea solstitialis & 20 & 8 & . & . & 29 & 50 & 5 \\
\hline Alyssum montanum subsp. repens & 16 & 8 & 11 & . & 23 & 36 & . \\
\hline Anthyllis vulneraria subsp. rubriflora & 18 & 8 & . & . & 6 & 100 & . \\
\hline Eryngium amethystinum & 17 & . & . & . & 6 & 100 & . \\
\hline Sideritis raeseri subsp. raeseri & 14 & . & . & . & . & 93 & . \\
\hline Stipa pulcherrima & 17 & 8 & . & 20 & 6 & 86 & . \\
\hline Koeleria lobata & 15 & . & . & . & . & 79 & 15 \\
\hline Hypericum rumeliacum & 16 & . & . & . & 11 & 79 & . \\
\hline Lomelosia argentea & 21 & . & 11 & 20 & 23 & 64 & 5 \\
\hline Teucrium capitatum & 17 & . & 22 & . & 14 & 64 & . \\
\hline Leontodon crispus & 12 & . & . & . & 9 & 57 & . \\
\hline Morina persica & 8 & . & . & . & . & 57 & . \\
\hline Cerastium decalvans & 7 & . & . & . & . & 50 & . \\
\hline Erodium absinthoides subsp. guiciardii & 9 & . & . & . & 6 & 50 & . \\
\hline Genista cf. depressa & 7 & . & . & . & . & 50 & . \\
\hline Minuartia attica subsp. attica & 8 & . & . & . & 3 & 50 & . \\
\hline Teucrium chamaedrys & 12 & . & 22 & . & 6 & 50 & . \\
\hline Achillea holosericea & 8 & . & 11 & . & . & 50 & . \\
\hline Sideritis montana subsp. montana & 13 & . & . & . & 17 & 43 & . \\
\hline Astragalus angustifolius & 6 & . & . & . & . & 43 & . \\
\hline Inula oculus-christi & 7 & . & . & . & 3 & 43 & . \\
\hline Prunus prostrata & 6 & . & . & . & . & 43 & . \\
\hline Onosma visianii & 5 & . & . & . & . & 36 & . \\
\hline Rosa villosa & 5 & . & . & . & . & 36 & . \\
\hline Acinos alpinus subsp. hungaricus & 8 & . & . & . & 9 & 36 & . \\
\hline Carex kitaibeliana & 5 & . & . & . & . & 36 & . \\
\hline Satureja montana & 5 & . & . & . & . & 36 & . \\
\hline Bupleurum falcatum subsp. cernuum & 4 & . & . & . & . & 29 & . \\
\hline Dianthus cruentus & 4 & . & . & . & . & 29 & . \\
\hline Orlaya grandiflora & 6 & . & 11 & . & 3 & 29 & . \\
\hline Thymus boissieri & 6 & . & . & . & 6 & 29 & . \\
\hline Trifolium fragiferum & 5 & . & . & . & . & 29 & 5 \\
\hline Draba lasiocarpa & 4 & . & . & . & . & 29 & . \\
\hline Herniaria parnassica subsp. parnassica & 3 & . & . & . & . & 21 & . \\
\hline Pimpinella tragium & 3 & . & . & . & . & 21 & . \\
\hline Sedum ochroleucum & 3 & . & . & . & . & 21 & . \\
\hline Bromus erectus & 4 & . & 11 & . & . & 21 & . \\
\hline Silene vulgaris subsp. prostrata & 4 & . & . & . & 3 & 21 & . \\
\hline Nardus stricta & 20 & . & . & . & . & . & 95 \\
\hline Luzula spicata & 19 & . & . & . & . & . & 90 \\
\hline Phleum alpinum & 14 & . & . & . & 3 & . & 60 \\
\hline
\end{tabular}




\begin{tabular}{|c|c|c|c|c|c|c|c|}
\hline Vegetation unit & 1 & 2 & 3 & 4 & 5 & 6 & 7 \\
\hline Alopecurus gerardii & 13 & . & . & . & . & . & 60 \\
\hline Silene roemeri subsp. macrocarpa & 13 & . & . & . & & . & 60 \\
\hline Geranium subcaulescens & 16 & . & . & . & 6 & 14 & 55 \\
\hline Avenella flexuosa & 11 & . & & . & . & . & 50 \\
\hline Bellardiochloa variegata & 11 & . & . & . & . & & 50 \\
\hline Geum montanum & 9 & . & . & . & . & . & 45 \\
\hline Veronica chamaedrys subsp. chamaedrys & 12 & . & . & . & 6 & . & 45 \\
\hline Dianthus deltoides & 16 & . & . & . & 17 & & 45 \\
\hline Campanula spatulata subsp. spatulata & 9 & . & . & & 3 & . & 40 \\
\hline Scleranthus perennis subsp. marginatus & 12 & . & . & . & 9 & . & 40 \\
\hline Thymus stojanovii & 8 & . & & & & . & 40 \\
\hline Vaccinium myrtillus & 7 & . & . & . & . & . & 35 \\
\hline Viola cf. velutina & 11 & . & . & . & 9 & & 35 \\
\hline Senecio rupestris & 12 & . & . & . & 11 & . & 35 \\
\hline Viola tricolor & 6 & . & . & . & . & . & 30 \\
\hline Juniperus communis subsp. nana & 6 & . & . & . & 3 & . & 25 \\
\hline Ranunculus sartorianus & 7 & . & . & . & 6 & . & 25 \\
\hline Genista tinctoria & 7 & & . & . & 3 & 7 & 25 \\
\hline Dianthus myrtinervius & 4 & . & . & . & . & . & 20 \\
\hline Pimpinella saxifraga & 4 & . & . & . & . & . & 20 \\
\hline Sagina saginoides & 4 & . & . & . & . & . & 20 \\
\hline Trifolium parnassii & 4 & . & . & . & . & . & 20 \\
\hline Veronica orsiniana subsp. orsiniana & 4 & . & & . & . & . & 20 \\
\hline Thymus praecox subsp. jankae & 5 & . & . & . & 3 & & 20 \\
\hline \multicolumn{8}{|l|}{ Other species } \\
\hline Potentilla recta & 39 & 58 & & 20 & 40 & 57 & 35 \\
\hline Achillea nobilis & 21 & 8 & 11 & 40 & 34 & 7 & 15 \\
\hline Acinos alpinum & 21 & 17 & & 20 & 26 & 36 & 15 \\
\hline Koeleria macrantha & 17 & & 56 & 20 & 17 & . & 20 \\
\hline Trifolium pratense & 14 & 17 & . & 40 & 9 & 7 & 25 \\
\hline Lotus corniculatus & 19 & & 11 & 20 & 20 & 7 & 40 \\
\hline Marrubium peregrinum & 15 & 8 & 33 & 20 & 20 & 14 & . \\
\hline Linaria peloponnesiaca & 17 & . & 22 & 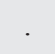 & 20 & 7 & 30 \\
\hline Minuartia recurva subsp. condensata & 15 & . & 44 & . & 23 & 7 & 5 \\
\hline Veronica arvensis & 15 & 8 & 11 & 20 & 23 & 7 & 10 \\
\hline Dianthus pinifolius subsp. lilacinus & 14 & 8 & 11 & & 17 & 36 & . \\
\hline Lactuca serriola & 11 & 8 & 22 & 20 & 14 & 7 & . \\
\hline Cerastium semidecandrum & 12 & 33 & 22 & & 14 & . & . \\
\hline Trifolium repens & 12 & . & 11 & 20 & 11 & . & 25 \\
\hline Sherardia arvensis & 13 & 33 & . & . & 17 & 7 & 5 \\
\hline Asperula purpurea subsp. apiculata & 12 & . & . & . & 9 & 21 & 25 \\
\hline Phleum phleoides & 13 & . & 22 & 20 & 11 & & \\
\hline
\end{tabular}


Table 3: Percentage frequency of diagnostic taxa of different classes in the six distinguished vegetation units (1: Koelerio-Corynephoretea, 2: Thero-Brachypodietea, 3: Stellarietea mediae, 4: Festuco-Brometea, 5: DaphnoFestucetea, 6: Juncetea trifidi).

Tabela 3: Frekvenca v odstotkih diagnostičnih vrst različnih razredov $\mathrm{v}$ šestih vegetacijskih tipih (1: Koelerio-Corynephoretea, 2: Thero-Brachypodietea, 3: Stellarietea mediae, 4: Festuco-Brometea, 5: Daphno-Festucetea, 6: Juncetea trifidi).

\begin{tabular}{lccccccc}
\hline & \multicolumn{7}{c}{ C I a s s e s } \\
Diagnostic taxa of (in \%): & $\mathbf{1}$ & $\mathbf{2}$ & $\mathbf{3}$ & $\mathbf{4}$ & $\mathbf{5}$ & $\mathbf{6}$ \\
\hline Koelerio-Corynephoretea & 30 & 19 & 9 & 20 & 6 & 5 \\
Thero-Brachypodietea & 7 & 26 & 7 & 8 & 4 & 0 \\
Stellarietea mediae & 11 & 8 & 21 & 7 & 3 & 0 \\
Festuco-Brometea & 18 & 14 & 10 & 22 & 21 & 11 \\
Daphno-Festucetea & 0 & 0 & 0 & 1 & 22 & 0 \\
Juncetea trifidi & 0 & 1 & 0 & 2 & 0 & 29 \\
Artemisietea vulgaris & 5 & 5 & 8 & 5 & 1 & 1 \\
Molinio-Arrhenatheretea & 1 & 2 & 9 & 5 & 1 & 8 \\
Other species & 28 & 24 & 35 & 31 & 40 & 46 \\
\hline
\end{tabular}

Table 4: Relevés of Koelerio-Corynephoretea in the Prespa area. Diagnostic species are according to Mucina (1997), Rūsiņa (2005), Kuzemko (2009) and Pedashenko et al. (2013). The location of the plots is given in Figure 1.

Tabela 4: Popisi razreda Koelerio-Corynephoretea iz območja Prespa. Diagnostične vrste so povzete po Mucina (1997), Rūsiņa (2005), Kuzemko (2009) in Pedashenko et al. (2013). Lokacije popisnih ploskev so podane na Sliki 1.

\begin{tabular}{|c|c|c|c|c|c|c|c|c|c|c|c|c|c|}
\hline Running number of relevé & 1 & 2 & 3 & 4 & 5 & 6 & 7 & 8 & 9 & 10 & 11 & 12 & \\
\hline Original number of relevé & 84 & 93 & 92 & 235 & 236 & 237 & 231 & 263 & 264 & 265 & 266 & 267 & \\
\hline Plot size $\left(\mathrm{m}^{2}\right)$ & 16 & 16 & 25 & 20 & 25 & 16 & 25 & 20 & 20 & 25 & 25 & 25 & $>$ \\
\hline Geology & $\mathrm{Al}$ & $\mathrm{Al}$ & $\mathrm{Al}$ & $\mathrm{Al}$ & $\mathrm{Al}$ & $\mathrm{Al}$ & $\mathrm{Al}$ & $\mathrm{Al}$ & $\mathrm{Al}$ & $\mathrm{Al}$ & $\mathrm{Al}$ & $\mathrm{Al}$ & ర్d \\
\hline Altitude (m a.s.1.) & 852 & 848 & 852 & 849 & 854 & 853 & 852 & 855 & 856 & 856 & 857 & 857 & Е \\
\hline Exposition $\left({ }^{\circ}\right)$ & 315 & 293 & 0 & 0 & 0 & 315 & 0 & 5 & 0 & 0 & 157 & 315 & $\begin{array}{l}0 \\
8\end{array}$ \\
\hline Inclination (\%) & 5 & 5 & 0 & 0 & 0 & 5 & 0 & 90 & 0 & 0 & 5 & 5 & 跑 \\
\hline Cover of vegetation (\%) & 60 & 50 & 90 & 60 & 60 & 60 & 70 & 95 & 70 & 60 & 70 & 90 & है \\
\hline Cover of shrubs $(\%)$ & 0 & 0 & 1 & 0 & 0 & 0 & 1 & 0 & 0 & 0 & 0 & 0 & \\
\hline Cover of herbs $(\%)$ & 60 & 50 & 90 & 60 & 60 & 60 & 70 & 95 & 70 & 60 & 70 & 90 & \\
\hline
\end{tabular}

\begin{tabular}{|c|c|c|c|c|c|c|c|c|c|c|c|c|c|}
\hline \multicolumn{14}{|c|}{ Diagnostic species of Koelerio-Corynephoretea (incl. Festuco-Sedetalia acris) } \\
\hline Cruciata pedemontana & + & + & + & + & 1 & + & + & + & 1 & 1 & + & 1 & 12 \\
\hline Rumex acetosella & 1 & 1 & 1 & 1 & 1 & 1 & 1 & + & 1 & + & 1 & 1 & 12 \\
\hline Poa bulbosa & 1 & + & 1 & + & 1 & + & 1 & . & + & + & 1 & 1 & 11 \\
\hline Trifolium arvense & + & + & 1 & 1 & 1 & + & 1 & . & + & 1 & 1 & 1 & 11 \\
\hline Linaria genistifolia subsp. sofiana & + & + & 1 & + & 1 & . & 1 & 1 & 1 & $2 \mathrm{a}$ & + & + & 11 \\
\hline Vulpia myurus & + & 1 & + & + & . & 1 & . & 1 & 1 & 1 & $2 \mathrm{a}$ & . & 9 \\
\hline Filago arvensis & + & . & + & 1 & 1 & 1 & + & . & $\mathrm{r}$ & . & $\mathrm{r}$ & $\mathrm{r}$ & 9 \\
\hline Petrorhagia saxifraga & $\mathrm{r}$ & . & . & $\mathrm{r}$ & + & . & . & . & $\mathrm{r}$ & . & $\mathrm{r}$ & + & 6 \\
\hline Trifolium scabrum & + & . & . & + & . & . & + & $\mathrm{r}$ & . & . & 1 & $\mathrm{r}$ & 6 \\
\hline Medicago minima & $\mathrm{r}$ & + & $\mathrm{r}$ & . & + & . & . & . & . & $\mathrm{r}$ & . & . & 5 \\
\hline Aira elegantissima & $\mathrm{r}$ & $\mathrm{r}$ & $\mathrm{r}$ & . & . & $\mathrm{r}$ & $\mathrm{r}$ & . & . & . & . & . & 5 \\
\hline Sedum acre & $\mathrm{r}$ & . & . & . & $\mathrm{r}$ & . & $\mathrm{r}$ & . & . & $\mathrm{r}$ & . & $\mathrm{r}$ & 5 \\
\hline Vicia lathyroides & . & . & + & . & + & + & + & 1 & . & . & . & . & 5 \\
\hline Trifolium campestre & + & . & . & . & + & + & . & . & . & . & . & . & 3 \\
\hline Sedum annuum & . & $\mathrm{r}$ & . & . & . & . & . & . & $\mathrm{r}$ & . & . & $\mathrm{r}$ & 3 \\
\hline Myosotis ramosissima subsp. ramosissima & . & . & + & $\mathrm{r}$ & . & . & + & . & . & . & . & . & 3 \\
\hline Arenaria serpyllifolia & . & + & . & $\mathrm{r}$ & . & . & + & . & . & . & . & . & 3 \\
\hline Berteroa incana & . & . & + & + & . & $\mathrm{r}$ & . & . & . & . & . & . & 3 \\
\hline Potentilla argentea & . & . & + & . & . & . & . & . & . & 1 & + & . & 3 \\
\hline \multicolumn{14}{|c|}{ Diagnostic species of Sileno conicae-Cerastion semidecandri } \\
\hline Silene conica & + & 1 & + & 1 & 1 & 1 & + & + & 1 & 1 & + & 1 & 12 \\
\hline Cerastium semidecandrum & $\mathrm{r}$ & . & + & . & . & + & + & . & . & . & . & . & 4 \\
\hline
\end{tabular}


$\begin{array}{lllllllllllll}\text { Running number of relevé } & 1 & 2 & 3 & 4 & 5 & 6 & 7 & 8 & 9 & 10 & 11 & 12\end{array}$

Diagnostic species of Silene frivaldszkyana-Erysimum microstylum comm.

Erysimum microstylum

Silene frivaldszkyana

Diagnostic species of Stellarietea mediae

Bromus rubens

Avena sterilis

Bromus squarosus

Lupinus angustifolius

Anthemis arvensis subsp. arvensis

Geranium purpureum

Bromus sterilis

Vicia hirsuta

Convolvulus arvensis

Diagnostic species of Artemisietea vulgaris

Anchusa officinalis

Cichorium intybus

Verbascum pulverulentum

Crepis setosa

Cynoglossum officinale

Diagnostic species of Festuco-Brometea

Eryngium campestre

Sanguisorba minor

Hypericum perforatum

Astragalus onobrychis

Galium verum subsp. verum

Herniaria incana

Melica ciliata

Helianthemum oelandicum subsp. canum

Convolvulus cantabrica

Lactuca viminea

Stipa capillata

Hieracium bauhini

Diagnostic species of Thero-Brachypodietea

Bromus hordeaceus

Trifolium hirtum

Taeniatherum caput-medusae

Dasypyrum villosum

Alyssum chalcidicum

Cerastium brachypetalum subsp. roeseri

Cynosurus echinatus

Petrorhagia dubia

Diagnostic species of Molinio-Arrhenatheretea

Trifolium pratense

Plantago lanceolata

Other species

Euphorbia myrsinites

Thymus sibthorpii

Torilis arvensis

Centaurea cuneifolia

Draba muralis

Scirpoides holoschoenus

Jasione heldreichii

$$
\begin{aligned}
& \begin{array}{ccccccccccccc}
+ & 1 & 1 & 1 & 1 & + & 1 & . & \mathrm{r} & + & + & 1 & 11 \\
. & 1 & + & 1 & + & . & 2 \mathrm{a} & + & 1 & 1 & + & . & 9
\end{array} \\
& +\quad+\quad 1 \quad 1++\begin{array}{lllllll}
+ & 1 & 3 & 1 & 2
\end{array} \\
& 1+\quad+\begin{array}{llllllllllll} 
& 1 & 1 & 1 & \mathrm{r} & + & + & + &
\end{array}
\end{aligned}
$$

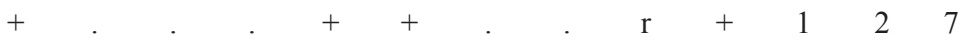

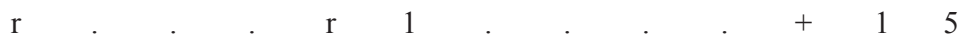

$$
\begin{aligned}
& \text {. }+\quad+\quad+\quad \text {. . . . . } 5 \\
& \text {. } \quad+\mathrm{r} . \quad \mathrm{r} . \quad . \quad . \quad 3
\end{aligned}
$$

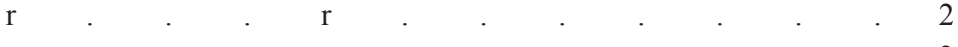

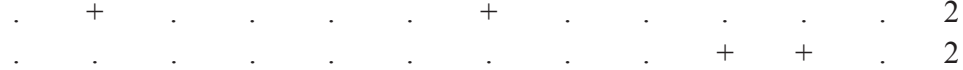

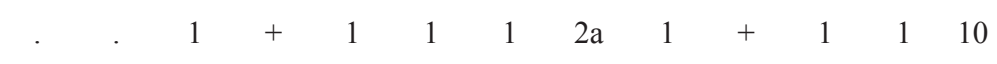

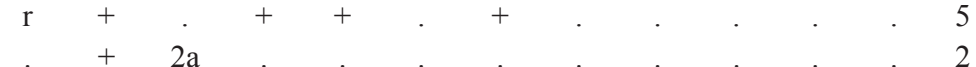

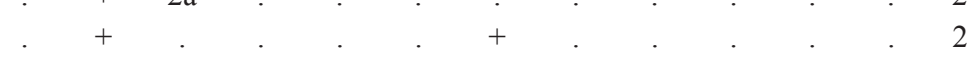

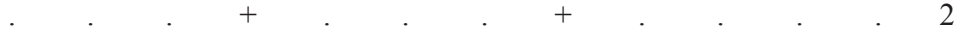

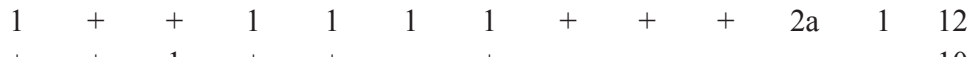

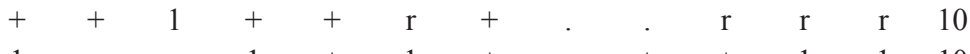

$$
\begin{aligned}
& \begin{array}{cccccccccccc}
\cdot & \mathrm{r} & 1 & + & 1 & + & \cdot & + & + & 1 & 1 & 10 \\
+ & + & + & 1 & & + & & \mathrm{r} & 1 & 2 \mathrm{a} & 1 & 9
\end{array}
\end{aligned}
$$

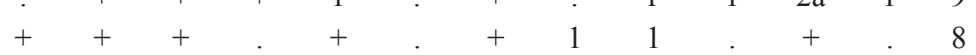

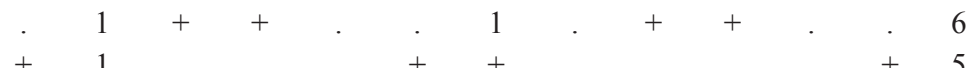

$$
\begin{aligned}
& \text {. } \mathrm{r}+. \quad \text {. } 1 \text {. } 1.0 .3
\end{aligned}
$$

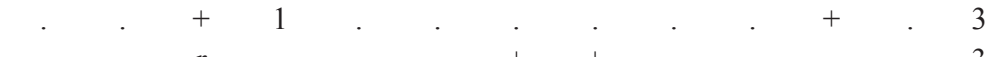

$$
\begin{aligned}
& .+r^{2}+r^{3}
\end{aligned}
$$

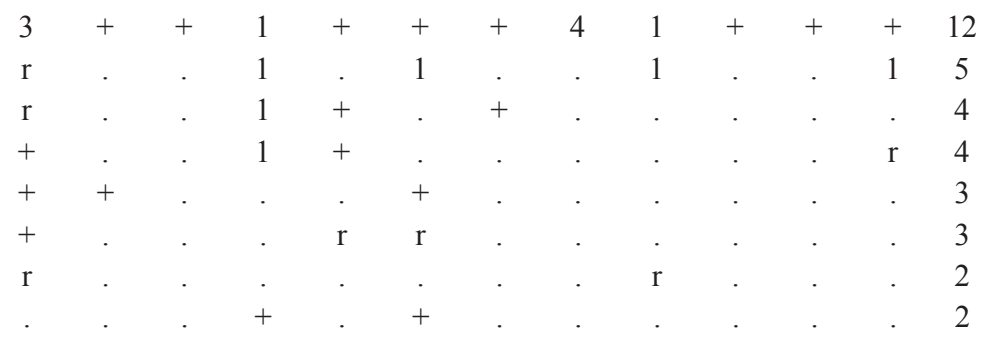

$$
\begin{aligned}
& \begin{array}{cccccc}
+ & \cdot & + & \cdot & \cdot & 2 \\
2 \mathrm{a} & \cdot & \cdot & 1 & \cdot & 2
\end{array}
\end{aligned}
$$

in




\begin{tabular}{|c|c|c|c|c|c|c|c|c|c|c|c|c|c|}
\hline Running number of relevé & 1 & 2 & 3 & 4 & 5 & 6 & 7 & 8 & 9 & 10 & 11 & 12 & \\
\hline Delphinium balcanicum & $\mathrm{r}$ & . & $\mathrm{r}$ & $\mathrm{r}$ & $\mathrm{r}$ & . & . & . & . & $\mathrm{r}$ & $\mathrm{r}$ & + & 7 \\
\hline Achillea coarctata & . & . & . & . & + & + & + & . & 1 & 1 & 1 & 1 & 7 \\
\hline Potentilla recta & . & + & . & . & + & . & + & + & 1 & . & + & + & 7 \\
\hline Euphorbia rigida & + & . & . & . & 1 & + & . & . & . & 1 & $2 \mathrm{a}$ & 1 & 6 \\
\hline Papaver rhoeas & + & . & $\mathrm{r}$ & . & + & . & $\mathrm{r}$ & . & . & 1 & . & . & 5 \\
\hline Tordylium maximum & $\mathrm{r}$ & . & $\mathrm{r}$ & . & $\mathrm{r}$ & . & . & . & . & $\mathrm{r}$ & . & $\mathrm{r}$ & 5 \\
\hline Hypericum olympicum & . & . & . & . & 1 & . & . & . & + & + & 1 & + & 5 \\
\hline Verbascum cf. eriophorum & . & . & . & . & . & . & . & + & 1 & 1 & + & 1 & 5 \\
\hline Sherardia arvensis & $\mathrm{r}$ & . & + & . & . & . & $\mathrm{r}$ & . & . & . & + & . & 4 \\
\hline Plantago indica & . & . & + & + & + & . & + & . & . & . & . & . & 4 \\
\hline Onosma heterophylla & . & . & . & . & + & . & . & . & + & + & + & . & 4 \\
\hline Stachys angustifolia & . & . & . & . & + & . & . & . & . & + & 1 & 1 & 4 \\
\hline Scabiosa webbiana & . & . & $\mathrm{r}$ & . & + & . & + & . & . & . & . & . & 3 \\
\hline Tragopogon porrifolius subsp. eriospermus & . & + & + & . & . & . & . & . & . & . & . & . & 2 \\
\hline Minuartia verna subsp. collina & . & . & . & . & + & . & + & . & . & . & . & . & 2 \\
\hline Acinos alpinus & . & . & . & . & + & . & + & . & . & . & . & . & 2 \\
\hline
\end{tabular}

Taxa in one relevé: Lathyrus sphaericus 1: r, Matricaria chamomilla 1: +, Phragmites australis 2: +, Petrorhagia prolifera 2: +, Rumex tuberosus subsp. tuberosus 2: +, Alyssum montanum subsp. repens 3: 1, Centaurea alba 3: 1, Astragalus depressus 3: +, Salix alba 3: +, Crepis sancta 3: +, Erodium ciconium 3: +, Potentilla recta subsp. laciniosa 3: +, Veronica verna 3: +, Cynodon dactylon 3: +, Echium italicum 3: +, Vicia villosa subsp. villosa 3: +, Anthyllis vulneraria subsp. rubriflora 3: +, Marrubium peregrinum 4: r, Saponaria officinalis 4: +, Achillea nobilis 4: +, Bellardia latifolia 5: r, Ajuga chamaepitys 5: r, Securigera varia 5: r, Galium cf. lucidum 5: +, Centaurea cyanea 5: +, Verbascum nigrum 6: +, Rosa canina 7: 1, Dianthus stenopetalus 7: 1, Dianthus pinifolius subsp. lilacinus 7: +, Lactuca serriola 7: +, Stipa pulcherrima 7: +, Mentha spicata 8: 3, Vicia grandiflora 8: 2a, Galium aparine 8: 1, Cirsium eriophorum 8: 1, Vicia angustifolia 8: +, Vicia lutea 8: +, Potentilla reptans 8: +, Origanum vulgare 9: 2a, Achillea grandifolia 9: 1, Centaurea solstitialis 9: 1, Plantago major subsp. intermedia 9: +, Hylotelephium telephium 10: +, Silene italica 10: +, Veronica arvensis 10: +, Tragopogon dubius 10: +, Festuca cf. varia 11: 1, Trifolium tenuifolium 11: +. 